\title{
Operation Teddy: A Compassionate Approach to Early HIV/AIDS Prevention Education
}

\author{
Lyndall Ellingson
}

California State University, Chico

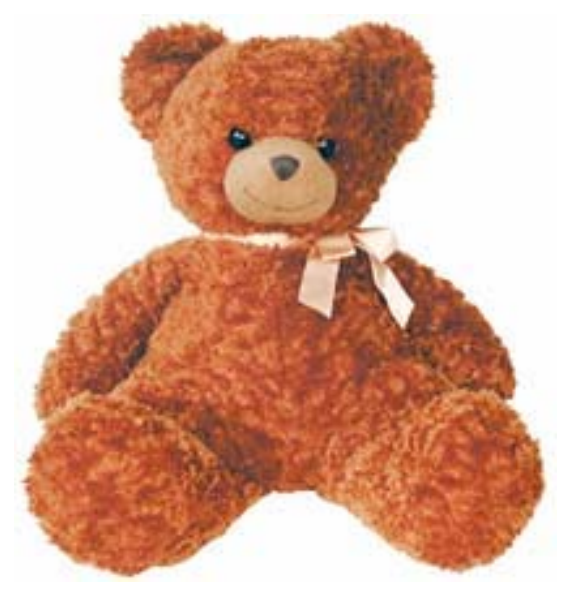

\begin{abstract}
Current adolescent HIV infection rates support the need for early HIV/AIDS prevention education. This article describes a successful service-learning project in which undergraduate health education students developed and taught an elementary school HIV/AIDS prevention education curriculum that included a compassion component involving donation of teddy bears to community members affected with HIV/AIDS.

(C) 2003 Californian Journal of Health Promotion. All rights reserved. Keywords: HIV/AIDS education, service learning, Family Life Education, Sexuality Education
\end{abstract}

\section{Introduction}

The HIV infection among adolescents continues to be a concern despite mandated HIV prevention education in the majority of states. In 1999, HIV was the fifth leading cause of death for Americans between the ages of 25 and 44. Many of these young adults were infected as adolescents and young adults (Centers for Disease Control and Prevention, 2001). It has been estimated that at least half of all new HIV infections in the United States are among people under 25 , and the majority of young people are infected sexually (Rosenberg, Biggar, \& Goedert, 1994). Furthermore, while there has been a decline in AIDS incidence in the general population, new infections among youth have not declined (CDC \& P, 2001).

It is clear that efforts are needed to reduce the rate of HIV infection among young people. One approach is to offer HIV/AIDS prevention education in the elementary grades before children begin normal adolescent exploration and risk taking. While this logic may seem obvious, the (perceived or real) political difficulties of implemented an early HIV/AIDS prevention program typically precludes such efforts. This article presents a successful HIV/AIDS prevention program for the elementary grades that has been met with praise by parents, teachers, administrators, and students alike.

\section{Program Overview}

Operation Teddy Bear was an elementary school HIV/AIDS education program conducted between 1998-2000 that combined HIV prevention content with compassion for those affected by HIV/AIDS. The "compassion" component was a key feature in the pedagogical and political success of this program. The program was designed around state and district health guidelines including the California Department of Education Health Framework (1994), which includes expectations that students demonstrate "concern toward ill persons in the family, the school, and the community" (p. 77) and understand disease 
transmission, prevention, and personal behaviors that put one at risk and protect one from infectious disease (p. 97-104).

The program had several components: 1) Service-learning and cognitive education: University health education students designed and taught HIV/AIDS prevention lessons to 5th6th graders; 2) Fund-raising: elementary school students raised money for teddy bears for those affected by HIV/AIDS by presenting musical concerts of K-12 school and local community choirs; 3 ) Affective education: individual teddy bears were adopted by students who personalized them with names, stories, and costumes; and finally, 4) A compassion ceremony: the bears were given by students to those affected by HIV/AIDS at a public ceremony.

Operation Teddy was originally initiated by teacher Ms. Jane Wolf in Southern California and won the 1996 MTV Peabody Award for Outstanding HIV/AIDS Education.

\section{Needs Assessment}

Prior to implementation, a needs assessment was conducted. The initial assessment evaluated California state, regional, and local school district guidelines for health education and found that the following were to be included in 5th-6th grade curricula:

a) communicable disease transmission and protection

b) sexually transmitted diseases including HIV

c) community health information resources

d) demonstrating concern toward ill persons in the family, school, and community, and understanding that people with diseases need the support and compassion of others.

A 1997 anonymous survey of local teachers and administrators found that little HIV/AIDS education was occurring despite these guidelines. Specifically, only four out of sixty seven 5-6th grade teachers in the district had taught or discussed HIV/AIDS transmission in the past two years (1996-1998).

\section{Program Goals}

The program sought to educate 5th-6th grade students on basic HIV transmission, disease, and prevention to reduce the likelihood of risk behavior and to provide a foundation for later HIV/AIDS education (Sigelman, Alfeld-Liro, Lewin, Derenowski, \& Woods, 1997). The program also focused on increasing student understanding of the stigma and need for compassion for individuals and families with HIV/AIDS by teaching compassion for those affected and putting a "human face" on the disease.

\section{Program Objectives Implemented}

Undergraduate health education students designed and implemented a nine-hour curriculum (three one-hour sessions per week for three weeks) and taught in teams of three. While there was variability in lesson plans, all addressed the following objectives:

Cognitive Objectives: Students will know:

a) how HIV is and is not transmitted

b) how HIV/AIDS impacts the body.

c) that personal behavior reduces or increases risk for most HIV transmission.

d) community sources of HIV/AIDS information

Affective Objectives: Students will understand:

a) that those with HIV/AIDS experience discrimination and stigma.

b) that those with HIV/AIDS should be treated with compassion.

c) how to improve the quality of life for HIVpositive children, adults, and families.

Some examples of lesson plan activities include the "Web of Connection" activity where students are led in an interactive discussion about linkages between behavior and disease transmission and prevention; an interactive True/False knowledge quiz that required students to move around the room; creating anatomical models to illustrate the effects of HIV on the immune system, word puzzles; and lecture/discussion. 


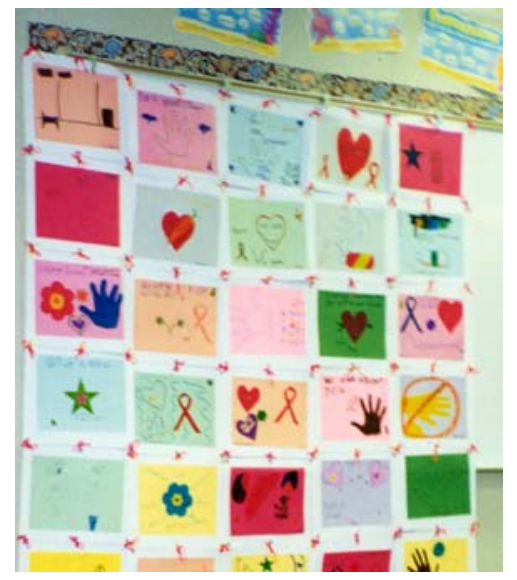

Figure 1

Construction Paper Quilt

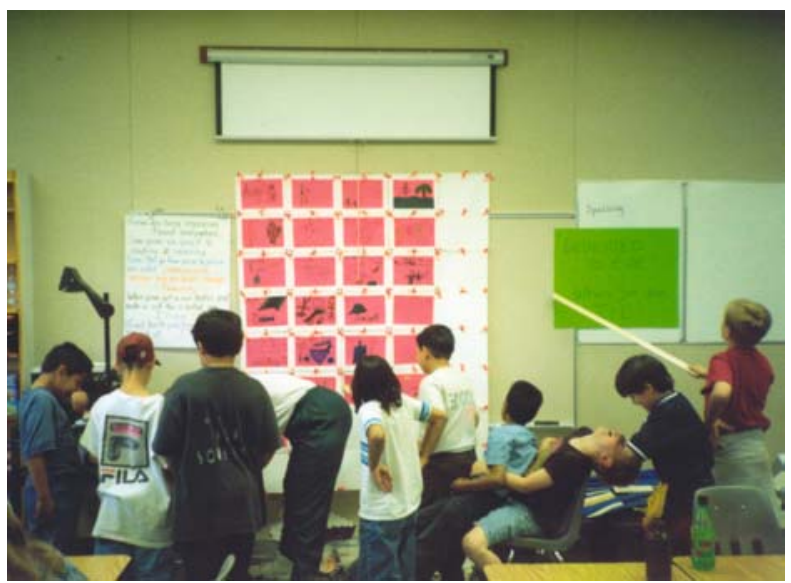

Figure 2

Children Hard at Work

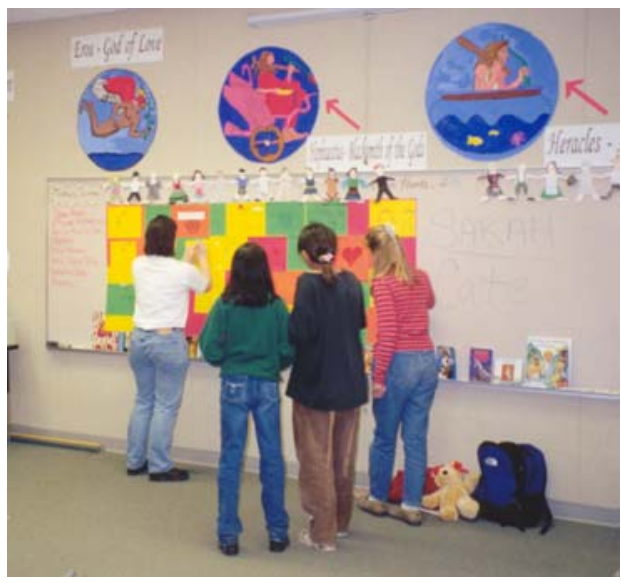

Figure 3

Girls Working on the Quilt 


\section{The Lovable Teddy Bear \\ or \\ The Teddy and me (and You)}

\section{By Beth Long}

This Teddy came to me,

It came to me so I could see

So I could see that love is needed

That love is needed even by those I do not know.

So I gave this Teddy love

I gave her love to pass along

To pass along to others who needed

To others who needed the love from me,

someone they did not know.

The Teddy was the key

The key to open my heart

To open my heart wide enough

Wide enough to let my love flow from me to you,

someone I'd like to know.

So keep this Teddy close by you

Close by you so you can feel the love

Feel the love pass from me to Teddy to you

And some day when you hold her close,

perhaps I will see you with Teddy

And we will know that we loved each other

in a very special way

with the help of a very special friend.

Figure 4

The Lovable Teddy Bear or The Teddy and Me (and You)

Reprinted with permission from Beth Long (\& her mother), Chico, California, 1998.

Affective objectives were approached using a Magic Johnson video (Arsenio Hall Communications, 1992) and discussion, art projects including construction-paper quilts (to mirror the AIDS Quilt Project) with themes like "what could I do with a friend with AIDS?" and "People with AIDS need ..."; (Figures 1-4) stories, poetry (attached), and the teddy bear adoption project. Near the end of the three-week educational program, students were given teddy bears to 'adopt'. They were asked to name them, create stories and costumes - essentially 'bring them to life'.

\section{Fundraising}

Fundraising was an integral part of the project. Fundraising efforts provided the necessary compassion component (bears), but more importantly it facilitated emotional investment among the elementary students and normalized the project for parents and the broader community. The Vice Principal of the 
elementary school organized the community benefit concert featuring several elementary and high school choirs and a community chorus (photo). Fourth - 12th grade students sold tickets to the event. Over $\$ 500$ was raised
(Figures 5 and 6). Additional funds were granted from the local Soroptomist International Chapter and a newspaper column charity drive. The bears were provided at cost from a large California manufacturer.

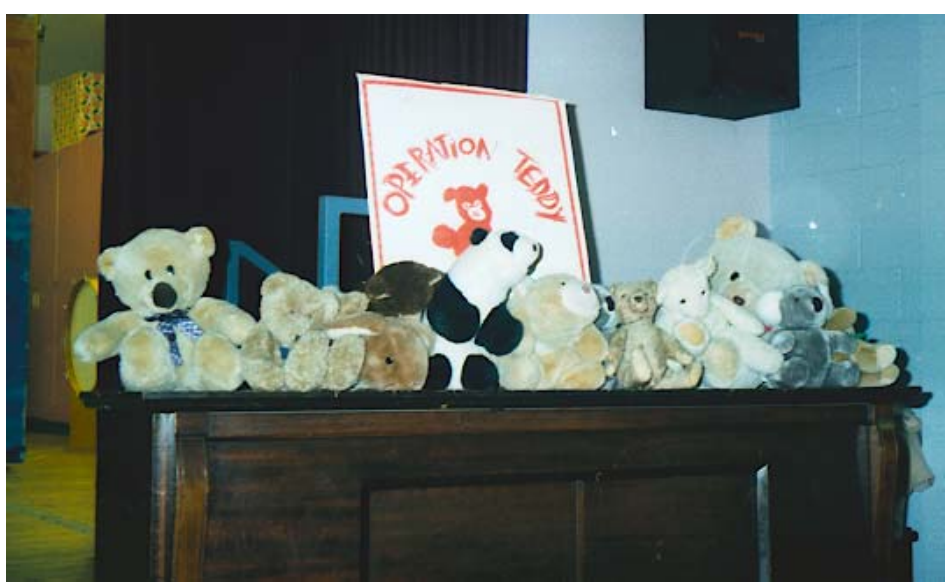

Figure 5

Bears on Piano Waiting for Concert to Begin

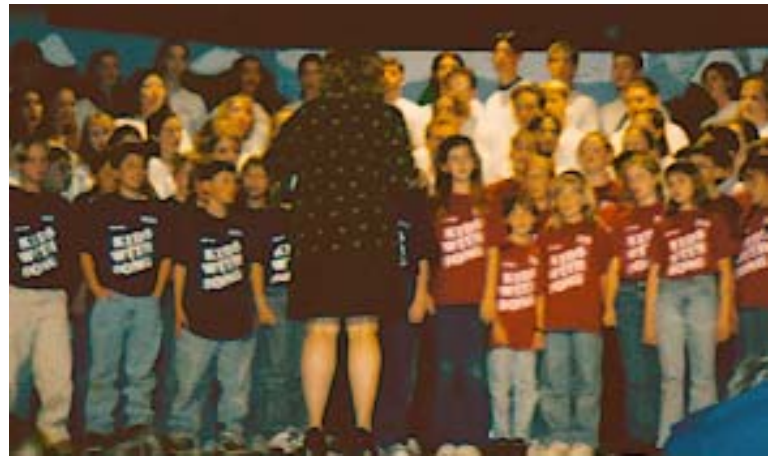

Figure 6

Fundraising Concert

\section{Operation Teddy Bear Ceremony}

The culminating event of the program is the Operation Teddy Bear ceremony during which each student gives her or his bear to an HIV+ person and professionals who serve those affected by HIV/AIDS (Figures 7-8). This ceremony included speeches from students (Appendix A), teachers, administrators, local dignitaries, and songs from the elementary school choir. Local AIDS quilt blocks were used to decorate the gymnasium. Undergraduate health education majors planned the Teddy Bear awards ceremony, including developing the agenda, contacting local dignitaries (primarily health and human service coordinators) to speak, submitting public service announcements, hosting parents, and handling the press. 


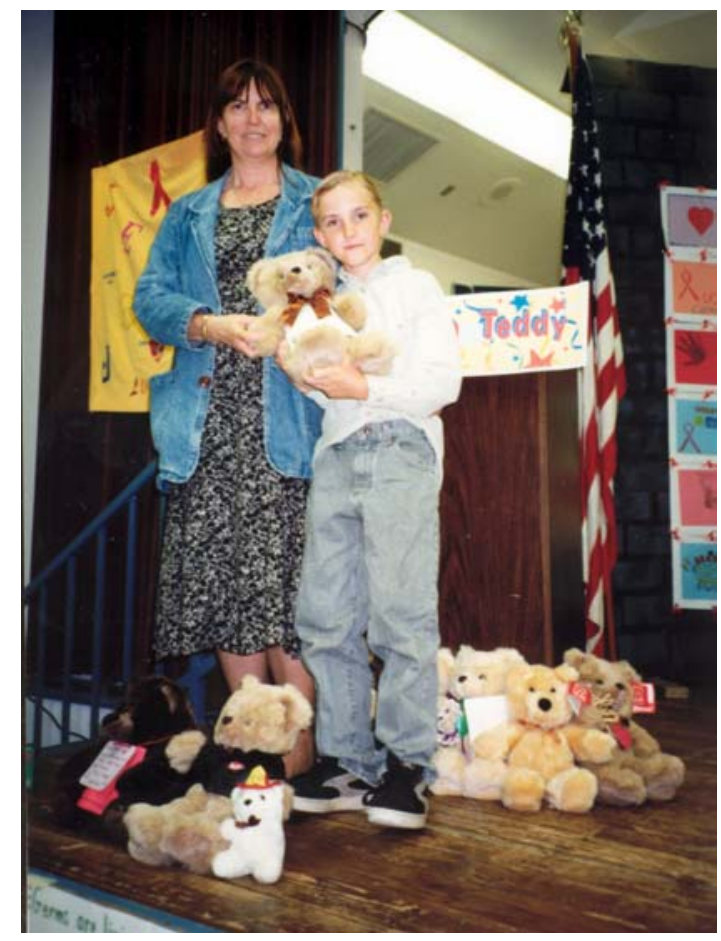

Figure 7

Student Ready to Donate Bear

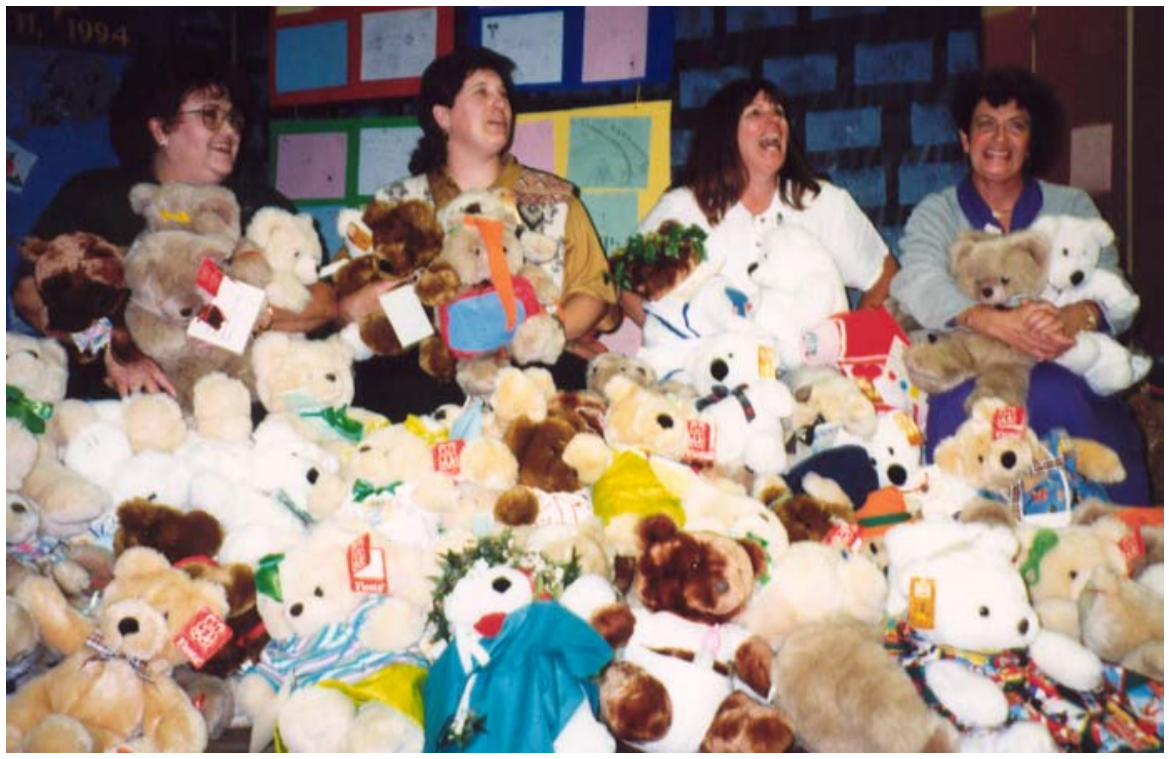

Figure 8

A Few Recipients of Donated Bears 


\section{Program Evaluation}

A process evaluation of the first-year program found all parties very pleased with the project. Undergraduate health education students answered anonymous survey questions with such phrases as "the most instructive and rewarding experience in my 5 years of college" and "I learned more about teaching and reaching students in this class than in all my classes put together." Elementary school students participated in follow-up discussions with their classroom teachers. Teachers reported a high level of conceptual understanding and receptiveness to prevention education among their students. The school and district administrative responses were equally positive the program was invited to participate in all the district schools the following year.

\section{Program Planning Words of Wisdom}

The success of this program rested on a few important factors: a) Do your homework: know your state, regional, and district guidelines and mandates.

b) Find your school and community gatekeepers to sponsor pilot project.

c) Start with and keep compassion as entry and focus (Nobody can resist a cute teddy bear!).

d) Find well-reputed and well-connected community members for fundraising;

e) Use 'service-learning' and town-gown relations as entry and justification.

\section{Summary}

The need is clear and so is the way. Parental and administrative concerns over elementary HIV/AIDS prevention education diminish when the program is grounded in approved guidelines and students are given the chance to give of themselves while they learn. Operation Teddy provided a vehicle to win the hearts and minds of parents, administrators and educators, while protecting the future of our youth.

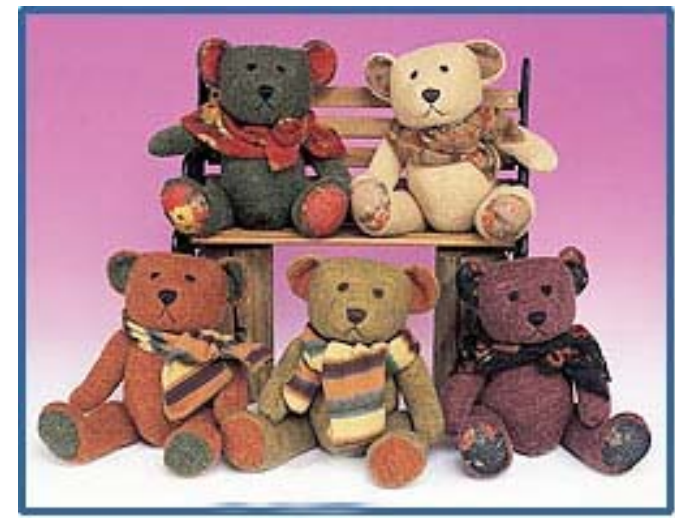

\section{Acknowledgements}

This project was funded by the Department of Health and Community Services at California State University; Chico, California Chapter of the Soroptomists International of Chico; Ms. Joan Jackson through her "Gourmet Diary" column in the Chico Enterprise-Record, and Fiesta Mahar Manufacturing Corporation. 


\section{References}

California State Department of Education. (1994). Health framework for California public schools kindergarten through grade twelve. Sacramento, CA: Author.

Centers for Disease Control \& Prevention. (2001). Young people at risk: HIV/AIDS among America's youth. Atlanta, GA: National Center for HIV, STD, and TB Prevention, Division of HIV/AIDS Prevention. Retrieved February 7, 2003, from http://www.cdc.gov/hiv/pubs/facts/youth.htm

Chico Enterprise Record. (2003). Home page. Retrieved February 7, 2003, from http://www.chicoer.com/

Rosenberg P. S., Biggar, R. J., Goedert J. J. (1994). Declining age at HIV infection in the United States [Letter]. New England Journal of Medicine, 330, 789-90.

Sigelman, C. K., Alfeld-Liro, C., Lewin, C. B., Derenowski, E. B., and Woods, T. (1997). The role of germs and viruses in children's theories of aids (or, AIDS are not band-aids). Health Education Behavior, 24, 191-200.

Author Information

Lyndall Ellingson, $\mathrm{PhD}$

Associate Professor,

Department of Health and Community Services

California State University, Chico

E-Mail: lellingson@csuchico.edu 


\title{
Appendix A
}

\author{
Speech by Megan Howard* \\ Emma Wilson Elementary School student \\ First Annual "Operation Teddy" Ceremony \\ Chico, California \\ May 6, 1998.
}

Today I will talk about compassion. Compassion for people who are sick. AIDS and HIV particularly. AIDS is a horrible disease. So is cancer and cysticfibrosis [sic] yet they seem different. Those diseases have a lot of compassion already. But it seems people with AIDS or HIV don't. Many people are afraid and uneducated about AIDS and HIV. They think giving someone a hug, drinking out of the same cup, eating off the same plate or being in the same room will get them the HIV virus. They are afraid to show compassion because they think casual contact will get them a deadly disease. The truth of the matter though is only using dirty needles, blood and so on will give you the deadly virus HIV which will give you AIDS. I think it is cowardly to be afraid to show compassion. All you are doing is giving someone a compliment or maybe even raising money to pay for some medication. Now, I do think everyone in here can at least give someone a compliment.

Showing compassion is showing tolerance. And tolerance is something everyone should show. Yes, a person may have AIDS, but what does turning your back on that person make you? It makes you intolerant and a coward as I have said before. But when you don't turn your back and you help a person who is sick then that makes you happy and them happy.

Imagine yourself knowing someone with AIDS. They may be treated badly, sick and lost their friends. You should be their friend instead of running away from a friendship.

It is up to you to make a difference so make all the difference you can.

\footnotetext{
* Reprinted with permission by Ms. Megan Howard.
} 